\title{
Constantin Silvestri, the problematic musician. New press documents
}

\author{
ALEX VASILIU, PhD \\ "George Enescu" National University of Arts \\ ROMANIA*
}

\begin{abstract}
Constantin Silvestri was a man, an artist who reached the peaks of glory as well as the depths of despair. He was a composer whose modern visions were too complex for his peers to undestand and accept, but which nevertheless stood the test of time. He was an improvisational pianist with amazing technique and inventive skills, and was obsessed with the score in the best sense of the word. He was a musician well liked and supported by George Enescu and Mihail Jora. He was a conductor whose interpretations of any opus, particularly Romantic, captivate from the very first notes; the movements of the baton, the expression of his face, even one single look successfully brought to life the oeuvres of various composers, endowing them with expressiveness, suppleness and a modern character that few other composers have ever managed to achieve. Regarded as a very promising conductor, a favourite with the audiences, wanted by the orchestras in Bucharest in the hope of creating new repertoires, Constantin Silvestri was nevertheless quite the problematic musician for the Romanian press. Newly researched documents reveal fragments from this musician's life as well as the features of a particular time period in the modern history of Romanian music.
\end{abstract}

Keywords: Romanian press; the years 1950; socialist realism.

\section{Introduction}

The present study is not necessarily occasioned by the $50^{\text {th }}$ anniversary of Constantin Silvestri's death ( $23^{\text {rd }}$ February 1969). On the contrary, we should speak of and write about Romanian historical, original, ever-fascinating personalities as often as possible, not merely on anniversary occasions. And Constantin Silvestri was such a dynamic, surprising and charismatic human being and musician, especially as revealed by the music that he created and recreated - and remained as such thanks to recordings and his salvaged sheet music - that it is worth our getting to know or returning to his world of thoughts, troubles, aspirations, great victories and despairs, or unfair battles. In a final and fundamental equation - in the world of revelations. Particularly revelations that occur with each audition of the works he wrote, the works he conducted, the ages he lived.

\footnotetext{
*alexvasiliujazz@gmail.com
} 
Constantin Silvestri is the only Romanian conductor mentioned or studied in six published works: in a chapter in Conductors and Orchestras and in Constantin Silvestri între străluciri și... cântece de pustiu (Constantin Silvestri between sparkle and ... melancholy songs) by Eugen Pricope, in Prietenii mei muzicieni (My musician friends) by Theodor Bălan, in Constantin Silvestri biografie necunoscută (Constantin Silvestri - an unknown biography) by Raluca Voicu Arnăuţoiu, and in the eponymous biography by Lavinia Coman. In the UK there are two published books: Constantin Silvestri, Magician: A View from the Orchestra by Raymond Carpenter and A Musician Before His Time. Conductor, Composer, Pianist by John Gritten. To these we can add the articles and studies published in Bucharest on the centenary of his birth (2013), as well as the recollections of musicologist and philosopher George Bălan captured in several 2019 - 2020 issues of the Muzica periodical and the two conferences in London and Bucharest on the $2^{\text {nd }}$ and $9^{\text {th }}$ November $2019^{1}$. All this comes to complete the picture of an original musician that has fascinated audiences and music researchers alike.

Constantin Silvestri's relationship with the Romanian press between 1945 - 1958 has never been studied in detail, to my knowledge, although it has been mentioned discreetly, in between the lines, covertly in the Romanian books published until 1989 and overtly after that year. There have been quotations, but they did not always conform to the sources and publishing date, in the Romanian books that I have mentioned. This time period is quite important as it reflects, on the one hand, the second segment which is decisive in Silvestri's musical evolution, and on the other hand the troubled, contradictory, even dramatic years that Romania experienced after World War II. The documents I have researched were published in the press of that time as news, lists, reviews, directives and editorials (or feature articles, as they were called then).

\section{Post-war artistic glory}

A first document to which I am referring is the weekly periodical Contemporanul (The Contemporary), issue $6 / 25^{\text {th }}$ October 1946. In the article entitled "Cronica muzicală. Filarmonica - Orchestra Radio" ("The Music Review. The Radio Philharmonic Orchestra"), author Virgil Gheorghiu commented on the series of concerts occasioned by the anniversary of the Romanian - Soviet friendship. Silvestri had conducted a George Enescu symphony (the author did not mention which one...), Rimski-Korsakov's Concerto for piano in C-sharp minor, Op. 30 (with pianist Irina Lăzărescu) and

\footnotetext{
1 London, $2^{\text {nd }}$ November, an event organised by the International Foundation Constantin Silvestri, King's College Archives and Special Collections Library, Radio România Muzical, ICR London and the George Enescu Museum. Bucharest, $6^{\text {th }}$ November, an event organised at the Cotroceni National Museum by Radio România Muzical with the support of the British Council Centre in Bucharest.
} 
Stravinsky's Feu d'artifice, Op. 4 (Fireworks) (at the time, Stravinsky was still tolerated by the communist regime). Today, Virgil Gheorghiu's writing style may make us smile, but, beyond that, it tells us the 'what' and the 'how' of the performance.

“(...) This important event was celebrated at the Romanian Athenaeum, where the Philharmonic Orchestra conducted by Mr Constantin Silvestri knew how to take part vivaciously in the expressive performance of the concert programme. (...) Feu d'artifice by Strawinsky (name misspelled in Romanian, our observation), a concessive composition by this revolutionary Western musician, exhibiting an impressionist harmonic lyricism, experienced an ideal translation of the imitative pyrotechnical intentions. An extremely virtuosic piece, particularly for the winds, Feu d'artifice concluded in a festive manner the concert of the $20^{\text {th }}$ October". (Gheorghiu, 1946a).

In issue $8 / 7^{\text {th }}$ November 1946 of the above-mentioned periodical, the same journalist wrote about the musicians that would have deserved to be invited to perform abroad, naming Eduard Lidenberg, Vasile Jianu and Constantin Silvestri (Gheorghiu, 1946b). History remembers Jianu as an excellent flautist, Silvestri as he deserves (as a conductor, too), but Lindenberg was never heard of anymore... The author wrote about Silvestri that "The Western world appreciates him as well he deserves, as a refined and intellectual animator". The diagnosis was accurate, but soon it would cost Silvestri dearly. For the time being, it was still possible to write about him, even weekly, as proven by the following issue of Contemporanul ( $\mathrm{n}^{\circ} 9 / 15^{\text {th }}$ November 1946), where the music journalist Virgil Gheorghiu wrote in sadness:

"An entire generation (...) of composers and performers have grown grey hoping they would get the right to artistic performance. I can see how difficult it has been for Nicolae Buicliu to have his symphony played, I can see Nicolae Brânzeu, Silvestri and so many others struggling to be performed" (Gheorghiu, 1946c).

Another week later, in issue $10 / 23^{\text {rd }}$ November 1946, Virgil Gheorghiu wrote:

"At the Philharmonic I had the pleasure of listening to $\mathrm{Mr}$ Constantin Silvestri who is becoming a first-rate conductor. He conducted a Brahms programme in optimal circumstances, and the orchestra responded by playing vivaciously. We 
listened to Brahms' Tragic Overture, Op. 81 and his Symphony No. 1 in C minor, Op. 68" (Gheorghiu, 1946d).

The critic noted that when the pieces were performed again as an educational concert there was an introduction by musicologist Emanoil Ciomac. Gheorghiu expressed his regret that Emanoil Ciomac did not introduce the music programmes on the radio as well. Indeed, after World War II, the tradition was broken with for nearly a decade, if we consider the fact that, between the two world wars, Emanoil Ciomac, together with Mihail Jora, Constantin Brăiloiu and Cella Delavrancea, had held several music conferences on the radio.

An encomium in issue $13 / 12^{\text {th }}$ December 1946 read:

"Mr Silvestri's improvisations are so alluring that to a lot of people who are uninitiated into the mysteries of modernism they prevail over the written compositions of this esteemed Romanian musician. Mr Silvestri is an endless source of pianistic fantasy and rhythmic-harmonic combinative knowhow" (Gheorghiu: 1946e).

A more generous article in terms of extent and praise was published in issue $31 / 26^{\text {th }}$ April 1947 of Contemporanul. Commenting on the programme that consisted of Virgil Pop's Symphony No. 3, Brahms' Violin Concerto in D major, Op. 77 and the Variations on a theme by Haydn, Op. 56, the critic Mircea Brucăr made his admiration known:

"The artist and conductor Constantin Silvestri's merit lies first and foremost in his wise choice of some truly significant pieces to highlight Brahms' artistic profile. The seldom-heard Symphony No. 3 in F major which, due to its pastoral-bucolic character, balances out the first symphonies full of romantic pathos, and the classical somberness of Symphony No. 4 was achieved by the Philharmonic orchestra only in the two central movements, as the orchestral ensemble did not follow further the conductor's subtle indications that exhibited full understanding of the Brahmsian style. Considering the actual possibilities of the orchestra, the interpretation that Constantin Silvestri was trying to render seemed to overestimate the performance abilities of the Philharmonic (...). The sumptuous sound of Brahms' Variations on a theme by Haydn occasioned Constantin Silvestri's triumphant success which his talent and exceptional qualification well deserve." (Brucăr, 1947). 
Let me now go back to 1946 as I must note that it was a glorious year for Constantin Silvestri himself and for Romanian music. Apart from the domestic triumphs, whose number cannot be found in the published reviews but can be inferred from the concert programmes of the Romanian Radio Society (SRR) (Cosma, 1999), apart from his success as a conductor in Budapest, Constantin Silvestri was inducted in the Romanian music hall of fame as the first conductor of several compositions by George Enescu. That was the first Romanian performance ever of the patricide scene from Oedipe, with tenor Constantin Stroescu, baritone Gabriel Popescu-Naruja and Constantin Silvestri as pianist.

\section{Censorship and marginalization}

When the communist regime took over, Silvestri met with several obstacles at the Radio. Apart from Theodor Rogalski and Alfred Alessandrescu, who were the established conductors of the SRR orchestra and who had become well-known in the '30s, two other conductors 'slithered' on to the rostrum: Matei Socor and Mircea Bârsan originated from Iași and were not so much authentic as appropriate to the political and ideologic maneuvers; they were more or less infamous for removing George Enescu and Antonin Ciolan from the music circles in Bucharest and Iași respectively. In the whole of 1946, Constantin Silvestri conducted the SRR orchestra only twice ( $7^{\text {th }}$ February and $1^{\text {st }}$ April), in 1948 only on $11^{\text {th }}$ March, and in 1947, 1949 and 1950 not even once. After two whole silent years, in 1951 he was scheduled a little more frequently: on $29^{\text {th }}$ March, $26^{\text {th }}$ April, $17^{\text {th }}$ May and $22^{\text {nd }}$ November to conduct a Beethoven programme and on $13^{\text {th }}$ December to conduct Mozart. I cannot say whether the fifth Beethoven programme, on $27^{\text {th }}$ March, was in fact his own wish to conduct only Beethoven in order to avoid as much as possible the Romanian and Soviet Proletkult compositions that had invaded the concert halls, or that it was the choice of the Radio Committee (that was what the management of the institution was called at the time) $)^{2}$. It is nonetheless certain that in some concerts he decided on a type of programme that was unusual even for Western European reputable orchestras: it would open with a long, difficult, complex piece, followed by a solo concerto and ending with a shorter piece or even another composition impressive in terms of writing and extent. For instance, the programme on $18^{\text {th }}$ November 1954, which was repeated four days later, consisted of César Franck's Symphony in D minor, Richard Strauss' Horn Concerto No. 1 in E-flat major, Op. 11, and in the second part the Suite "Pictures at an Exhibition" by Mussorgsky - Ravel. Performed in concert in a

\footnotetext{
${ }^{2}$ As much as possible, because in those years Silvestri was forced to include such compositions in the concert programmes of the SRR orchestra. Just as an example, on $6^{\text {th }}$ January 1953 , at 5:40 p.m., Radio Bucharest broadcast the "Epic poem" on traditional Russian themes by the young Soviet composer Golynin with the SRR orchestra (cf. The Radio Programme, year III, no. $60,2^{\text {nd }}$ January 1953 , page 2 ).
} 
city park in Bucharest, this type of programme received a negative review from Gabriela Deleanu in issue $106 / 8^{\text {th }}$ October 1948 of Contemporanul (Deleanu, 1948). The critic wrote about the opening of the 1948-49 season at the Philharmonic and reproved the conductor for choosing Bach's Brandenburg Concertos instead of opening with an overture. We may deduce that Silvestri was not among those favoured by the regime, given the facts that, between January and October 1948, there had been no music articles published in Contemporanul and Silvestri, although praised in the beginning, was now being reprimanded, while Gabriela Deleanu was manager of the Music Department. Moreover, Silvestri was the first musician to be subjected to criticism after Contemporanul, one of the most influential periodicals in the country, had taken such a long break from music articles.

Silvestri's procedure was then, and would be today, unconventional indeed; it is problematic for the audience, that is why it has not become common practice. But why did Silvestri use it? I am inclined to believe that it was because of his pride, because he wanted to exhibit to the whole city and to the authorities his great capabilities in interpreting difficult, complex oeuvres. His pride can be proven with documentary evidence. Having to endure, up until the end of World War II, his fellow musicians' (and implicitly the audience's) reserve towards his symphonic and chamber compositions written in a modern, evolved language that was inaccessible to many, more traditional, musicians, Constantin Silvestri was not well-liked by the new regime either. Besides, as the country proclaimed itself a republic, the left orientation led to a dictatorship and the Romanian Communist Party adopted mechanically and obediently the Soviet policy. The field of music was no exception: the situation began to deteriorate dramatically in February 1948, when Moscow issued the Directive of the Central Committee (b) of the Communist Party of the Soviet Union regarding music composition and criticism. Several important Soviet composers, such as Dmitri Shostakovich, Sergei Prokofiev and Aram Khachaturian were accused of formalism, breaking with the people, cosmopolitism, and were forced to apologise publicly and then write music according to the official cultural policy ${ }^{3}$, which led to such consequences as Shostakovich being banned from concert performance and broadcast, and his removal from the Conservatory. Without delay, in issue $76 / 12$ March of Contemporanul, the composer and professor Alfred Mendelsohn signalled how the Soviet model was adopted by Romania in his article entitled "O nouă orientare în muzică, pe marginea hotărârii C.C. al P.C (b) al Uniunii Sovietice cu privire la creația și critica muzicală" ["A new orientation in music based on

\footnotetext{
${ }^{3}$ Examples are aplenty: Poem about Stalin ("Song of the Ashug”) by Aram Khachaturian and, perhaps the best-known, the oratorio Song of the Forests, Op. 81, written by Shostakovich right after the Plenary Session in Moscow in February 1948.
} 
the Directive of the Central Committee of the Communist Party (b) of the Soviet Union"]. Even though music reviews had been absent from Contemporanul for five weeks prior to Mendelsohn's article, after $12^{\text {th }}$ March they disappeared completely from the contents of the periodical, probably because for the following three months the Moscow event caused confusion among the management of all music institutions as they expected a decision to be taken within the higher levels of the Party. After this break, the music articles and reviews in Contemporanul began to be authored particularly by high-ranking members in the Music Department such as Gabriela Deleanu or M. Crișan, by obedient or highly-obedient scribes such as I. Hristea or, beginning with 1949, George Bălan, by managers of various music institutions (such as Sabin Drăgoi, the Director of the Romanian Folklore Institute, or Mauriciu Vescan, manager of the Bucharest Opera), by some secretaries in the Composers' Union and directors within the SRR. Composers were required to write music for the masses to please all tastes, drawing inspiration not only from the rural tradition (as was specifically mandated in a series of articles), but also from the revolutionary urban music tradition of the working class. This marked the beginning of Constantin Silvestri's fall from grace, or rather disappearance from the press, since it was known that neither his radically modern compositions, nor those inspired by Transylvanian folklore met with the ideological requirements of the time.

In the following years, as a great many composers wrote songs, symphonies, cantatas, oratorios and even operas dedicated to the Party, to the Soviet leader Joseph Stalin, to the Secretary General of the Romanian Communist Party, Gheorghe Gheorghiu Dej, even to the Danube - Black Sea canal, the "Vladimir Ilyich Lenin" hydroelectric power plant in Bicaz or some national agricultural communes, Constantin Silvestri's works, which were free from any political constraints, could neither be performed nor broadcast anywhere in Romania. The repertories of Romanian orchestras would include, for the following decade, a large number of Proletkult compositions by Matei Socor, Hilda Jerea, Ion D. Chirescu, Mihail Andricu, Nina Casssian, Marcel Breslașu, Theodor Grigoriu, Alfred Mendelsohn, Paul Jelescu, Anatol Vieru, Ion Dumitrescu, Viorel Doboș, Nicolae Kirculescu, Vasile Popovici and Mauriciu Vescan, to name but a few, so Constantin Silvestri's symphonic and chamber music was completely left out. Not even his name made it into the ever so rare reviews that somehow managed to elude censorship and be published. Most music articles were in fact pseudo-reviews which named the composers, the pieces performed and the soloists, but with no mention whatsoever of the conductor. By researching the concert brochures of the SRR orchestra, I have found that Silvestri actually conducted some of the concerts reviewed in the press, but the critics omitted his name altogether. He was undisputedly a great conductor, even though certain scribes presumed to criticise him either openly 
or in a more veiled manner (two examples in this respect being the critic George Bălan and the pianist Irina Lăzărescu).

\subsection{Silvestri: "On the issue of form and content in music"}

Although two years had passed since Moscow's infamous Directive on music composition and criticism, Romania was, surprisingly, only beginning to experience the repression. The 'combat field' was set to be the magazine Flacăra (The Flame), a weekly periodical of the arts (theatre, music, visual arts). Issue 25 (129) / $24^{\text {th }}$ June 1950 hosted a first act of the campaign that was preparing the Romanian version of the 1948 Soviet Directive. This was the opening episode of the series that was beautifully named "For a wide debate of musical issues." At the time, on the first page of any Romanian publication there was a 'feature article' (nowadays called an 'editorial') which was always unsigned, where one of the Party's high officials or the editor-in-chief set the compulsory trend to be followed in a particular field. Therefore, the beginning of the so-called "debate" may be regarded, in light of everything that is known to have occurred, as a warning to all Romanian musicians to align themselves with the Soviet-born communist policy. In the issues of $30^{\text {th }}$ June, $8^{\text {th }}$ July and $22^{\text {nd }}$ July, the almost conformist articles were penned by Alfred Mendelsohn (from whom, though, the magazine had previously distanced itself in some respects), George Bălan, Zeno Vancea (secretary of the Composers' Union), Anatol Vieru, Robert Rosensteck (conductor at the Opera), and Ion Arbore (music student at the Conservatory in Bucharest). Naturally, as was the rule at the time, the conclusions were drawn by one of the heads of the Music Department, namely Eugen Rodan. The official trend set by Moscow, which the Romanian authorities had already begun to follow for a few years, established these priorities for all musicians: the fight against formalism, cosmopolitism, impressionism and avant-gardism in Western European and American cultures, as well as the necessity to endow every musical work with realism - evidently, socialist realism. There was a plea for programme music which was meant, much like all the other art forms, to capture the subject, and this relationship between the form and the contents came to cause a lot of ink to be spilled in the newspapers, magazines and books published during the first communism decades in Romania.

As a successful conductor, Constantin Silvestri was asked to give his opinion in Flacăra magazine. Why not also George Georgescu, who was older and equally prestigious? Considering what came to happen a year later, it is my opinion that Silvestri was implicated in that staged debate because his opinions were well-known, as he was dangerously honest at the time, and because the written proof would be subsequently used as evidence against him. In total antithesis to the official directives, Constantin Silvestri wrote the article "On the issue of form and content in music", published in Flacăra no. $30 / 29^{\text {th }}$ June 
1950. When he wrote the text, Silvestri was well aware that he was not abiding by the ideological canons, but, nonetheless, he expressed his faith (openly and idealistically for that period) in the clarifying virtues of opinion exchange.

"Naturally, I do not claim that the opinions I am about to express openly are entirely just; however, by confronting and scientifically reviewing various, and why not, contrasting, standpoints, we shall be able to gain new advanced perspectives. (...) Musical content cannot exceed the range of general inner values. A musical work encompasses such inner feelings as melancholy, enthusiasm, joy etc., without our being able to state the conditions or specific circumstances which allow for these feelings to develop. Naturally, when associated to a text or literary argument, a musical work can elicit more concrete, even particular things. But generally, it is the melody that becomes more popular with the masses of listeners, while in most cases the text is overlooked. As this happens, that particular musical work loses again its ability to express more concrete, ordinary things: hence, its foundation remains its general spiritual content. For instance, can Schubert's Lindenbaum - if listened without words, as it usually happens - evoke all those images painted by the lyrics, or does it merely elicit a feeling, such as a melancholy meditation? The latter is of course possible. Therefore, let us not require music to be precise; let us not chase in this art form for such well-defined pictures of everyday life as literature or the visual arts can provide. But this does not make music an abstract art. On the contrary, its concrete character lies in the emotional intensity that it can bring forth, in the rich array of overtones that can be displayed by the general spiritual content of music." (Silvestri, 1950, p. 4)

Believing that he might trick the censors by taking some precautions, Silvestri gave as examples several Proletkult symphonic works of the moment: Alfred Mendelsohn's Symphony No. 3 and New crop fields in the meadows of the Prut River by Sergiu Natra. Nevertheless, he went on and, holding true to his opinion, pleaded for the composer's resourcefulness:

"by innovations in terms of the complexity of the melodic phrase, the harmony, the counterpoint, the orchestration, the musical forms etc." (Silvestri, 1950, p. 4).

In this manner, Silvestri distanced himself from the official guidelines on the simplicity of music in order to be understood by anyone. Moreover, by 
taking a stand against the requirement that all composers should write certain types of music ${ }^{4}$, Silvestri said:

"(...) With respect to choosing a form of expression (sonata, symphony, poem, quartet, cantata, oratorio, opera etc.) there is no strict determination entailing from the content requirements. For instance, the Soviet people's love for Comrade Stalin found its fortunate expression in the Song for Stalin by Blanter, the Cantata to Stalin by Alexandrov and the Poem about Stalin by Khachaturian, three exquisite musical forms. (...) It often happens that the composer, starting from an expressive device, creates a work that has a content (...), and these devices themselves encompass a content." (Silvestri, 1950, p. 4).

In the conclusion of the article, on a moderate but firm tone, Constantin Silvestri stated his ideas on content and form in music, and suggested rather clearly that critics should refrain from discussing matters they do not understand:

"One should not exaggerate the presence of content in music. Oftentimes, in order to make the expression of the content even more obvious, classical and romantic composers employ what I would call neutral bridges, which lack content and whose whole purpose is to connect the musical ideas, to highlight them. For instance, in Beethoven's symphonies we encounter such bridges that connect melodic phrases as well as their development. (...) When light will be shed on this matter, we will of course know better to what extent we, the creators, can reflect life realistically, and the critics will have a better understanding of what they can demand of a work of music." (Silvestri, 1950, p. 4).

Obviously, Constantin Silvestri was not only referring to professional music critics, but particularly to the authors of propagandistic reviews: politruks, lowly musicians and, sadly, even true musicians who promptly embarked (some genuinely, others opportunistically) on the only ship that could save them then, in the 1950s, - the ship of Stalinist-communist ideology.

Naturally, Silvestri's article, that came at odds with the official requirements, was met with disapproval. The first reaction came from one of the most vocal and keen supporters of Proletkult policies. In order for everyone

\footnotetext{
${ }^{4}$ By copying the Muscovite trend, Romanian composers were required to write music with text, particularly opera.
} 
to know how 'wrong' Silvestri was, Mauriciu Vescan was quick to answer. For nearly sixty years now, nobody has mentioned his name, but between 19451963 the man was a vigilant and intransigent revolutionary, though he did not excel either as a conductor or as a composer. His only satisfactory composition was a pop song called În Bucureștiul iubit (In Beloved Bucharest) which played extensively between 1950-1960. Among his other compositions there was another equally fashionable song, Hei, rup (Here we go). Vescan was of course rewarded accordingly by being named director of the Bucharest Opera. The title of his article that was published in two instalments in Flacăra magazine was quite explicit regarding what was to follow: "Concerning some confusions on the issue of the national form and the socialist content in music."

Referring, among others, to the example chosen by Silvestri - Schubert's Lindenbaum, Mauriciu Vescan believed that

"This final paragraph reveals the composer Silvestri's grave mistake that the Comtesse de Pompadour's feeling of love should be the same as that of the working woman who builds socialism, and consequently there would be no difference in intonation between the two pieces. There would be no difference between the $18^{\text {th }}$ century bourgeois revolt against the nobility and the French docker's revolt who throws into the sea the weapons of American imperialism, therefore there would be no difference in intonation in those songs of revolt either, because the feeling of revolt remains the same along the centuries. But to solve the problems in this manner means to find metaphysical solutions, unconnected to real life, meant to distract the composers from reflecting all the wonderful realities of our developing socialist country, and to lull them into believing that their works, however mystical and decadent they might be, could become successful if sang on construction sites, for example (...).” (Vescan, 1950, p. 4).

The second reply to Silvestri's article came from George Bălan. Having the advantage of the two months and a few days that had passed since the publication of Constantin Silvestri's article, George Bălan wrote an extensive text that was published in two instalments in Flacăra magazine $\left(2^{\text {nd }}\right.$ and $9^{\text {th }}$ September 1950), entitled "With regard to the socialist content in music." George Bălan was highly critical of Silvestri, too, although he did not mention his name explicitly:

"(...) Those musicians who, alleging the so-called vague character of music, deny its possibility to express straightforwardly the new realities in our country, by stating that music has a general spiritual content irrespective of the 
historical development - which leads inevitably to the conclusion that this art form breaks with life, with the living reality. The drumbeaters of this theory [such a harsh word towards a remarkable musician like Constantin Silvestri, A/N] claim as argument a part of the musical output that is sometimes bound to an artistic conception that is foreign to socialist realism. By taking as an example these works with a wrong content, marred by a wrong form, they claim that music in general is not able to express life veraciously. (...) Clearly, music can and must reflect the new realities in such a manner that there be no doubt as to its expressing a completely new content and, contrary to what comrade Silvestri has stated, it is obvious that music, with its artistic character, cannot be a field isolated from the other arts, and therefore socialist realities can be depicted in music as well as in literature or the visual arts." (Balan, 1950).

There is not enough room to quote more from George Bălan's extensive articles which were critical of Constantin Silvestri from a socialist realistic perspective. Silvestri's replies came in later years, when he conducted Dmitri Shostakovich's Symphony No. 1, Op. 10, followed by the Symphonies No. 5, Op. 47, No. 8, Op. 65, and No. 10, Op. 93; the last three were in fact a musical reflection of the tragic times of Stalinist terror in the Soviet Union between 1933-1941, and after the Second World War. Two of the most convincing arguments, in fact quite overwhelming to the audience, were and still are Silvestri's 1955 and 1956 amazing performances with the SRR orchestra of Shostakovich's Symphony No. 10 in C minor, Op. 93, which were fortunately not only committed to the memory of critics and saved in several reviews, but also recorded on vinyl. Moreover, Shostakovich himself was astonished when he heard his Symphony No. 8, Op. 65, conducted by Silvestri in Moscow in 1958 , and his reaction was recalled later, in 2019, by George Bălan who had witnessed the meeting between the Russian composer and the Romanian conductor. (Bălan 2019, p.92-93).

Coming back to the 1950 campaign, the last opinion expressed in Flacăra no. $37 / 16^{\text {th }}$ September 1950 was that of the composer and professor Zeno Vancea. His openly critical stance, unexpectedly harsh of Mauriciu Vescan, is in fact understandable. He had known Silvestri quite well, ever since he had taught him at the Conservatory in Târgu Mureș, he had followed Silvestri's evolution in Bucharest and could not but acknowledge the obvious difference in professional quality between Silvestri and his detractor, Mauriciu Vescan. Zeno Vancea's article would be well worth quoting, at least in part. Again, as expected, the article hindered the official plans, because Silvestri should not 
have been defended, and the so-called 'debate' could end up badly for those who had orchestrated it. Consequently, a week later, Flacăra no. $38 / 23^{\text {rd }}$ September 1950 marked the end of the series by reproducing a long new article from the Muscovite magazine Sovetskaya Muzyka of August 1950. The article was so imbued with the ideology of the 1948 Directive that it was deemed the best answer, the best conclusion to all that had been discussed in the previous issues of Flacăra. Thus, the management of the Romanian magazine hid behind anonymity, and the officials in Bucharest washed their hands of the entire business, using as a screen the official Soviet document that was followed without question. To clear all doubts, a note from the Romanian editor was added above the text translated from Russian:

"Due to the way in which it analyses the works of our various

composers, this article helps clarify some important issues regarding musical composition and criticism."

In that particular political context, the Romanian strategy was, naturally, quite successful, as proven by the musicologist I. Martynov, secretary of the Soviet Composer's Union, who, during a long 'research' visit to Romania in the summer of $1951^{5}$, wrote a big article for the magazine Contemporanul no. 257 ( $7^{\text {th }}$ September 1951) where he mentioned, among others, the composers that had been criticised in the Flacăra debate, namely Leon Klepper and Constantin Silvestri. This resulted in Silvestri's absence as a composer from the "Week of Romanian Music" that took place between $22^{\text {nd }}-30^{\text {th }}$ September 1951 which was particularly relevant since he was also absent from the Plenary Session of the Composers' Union $\left(26^{\text {th }}-28^{\text {th }}\right.$ September) which brought up again the "sterilising effect of decadence and formalism", "the use of restricted intonations, idyllism - a remnant of the bourgeois sămănătorist trend, and the limitations of the intonational possibilities of our traditional music due to the unilateral usage of conventional rhythmic or melodic aspects. (...) Constantin Silvestri's 'Dansuri bihorene' ('Dances from Bihor County') for string orchestra cultivate quirkiness, the look for eccentric, manneristic effects, diminishing the wide array of feelings in traditional music to a limited range of whimsical, sometimes even morbid, moods." (Mendelsohn, 1951, p. 1).

Four years later (quite surprisingly), in February 1952, similarly to Moscow 1948, the Soviet model was copied at the Larger Plenary Session of the Composers' Union on $4^{\text {th }}-5^{\text {th }}$ February. The text of the Resolution was very critical of several composers, among whom one teacher and his student Mihail Jora and Constantin Silvestri. The opinions on Constantin Silvestri read as follows:

\footnotetext{
${ }^{5}$ This was actually a check-up visit, as was the fashion in all fields of activity in the years when various counsellors and leadership in the USSR investigated what was happening in Romania.
} 
“Constantin Silvestri's works 'Three Dances' for string orchestra proves that its composer is still under the heavy influence of formalism. This atonal and extravagant composition deforms traditional intonations." (*** Muzica, nr. 6/1952, pp.7-8).

\section{Conclusions}

It was the continuous criticism of his oeuvre, the refusal of those in charge to allow the performance of his compositions, his passion for conducting and ultimately the need to earn a living that made Constantin Silvestri take up the baton with an out-of-the-ordinary enjoyment, passion and thoroughness. His stylistic comprehension abilities, the virtuosity of his conducting various works of the Russian and Soviet repertoire, his success as conductor of Moscow and former Leningrad orchestras in 1954, as well as the admiration of Shostakovich himself secured his fame, ensuring his 'safety' at home, in Romania. The same happened in other socialist countries such as Czechoslovakia ${ }^{6}$. His connection to Shostakovich can also be claimed due to the similar attitude of the USSR and Romanian officials towards the two musicians. They rose and fell in turn on tides of the acceptance or refusal of their oeuvres, they were awarded important distinctions, they were criticised, always under suspicion, they were permanently at odds with the authorities who, when in need, did not hesitate to bring them to the forefront and use their well-earned reputation.

Constantin Silvestri's great advantage was his as prestige a conductor. His excellent repute was widely acknowledged in the socialist countries and in Western Europe. Nonetheless, he was often denied a travel visa to the West, and the conductor George Georgescu, who was well-liked by the authorities, was envious of Silvestri and would often taunt him on that score. However, after George Enescu's death, the high officials of the Party and state decided to organise the international festival that would bear his name. To earn fame, the regime invited well-known musicians from the former Soviet Union and the Western European countries, and involved Constantin Silvestri twofold: as president of the piano section in the international competition that took place at the same time as the festival, and as composer, some of his works being programmed in a series of concerts during the festival. The concert of $18^{\text {th }}$ June 1956, which occasioned the first Romanian audition of Silvestri's Decet for winds, Op. 13, and his Chamber Symphony, Op. 33, was truly unforgettable. The memory of the Sonata for violin and piano that Silvestri had performed ten years before, in 1946, had not faded...

\footnotetext{
${ }^{6}$ George Enescu's two Romanian Rhapsodies were recorded by Constantin Silvestri with the Czech orchestra on Supraphon - LPM 310, Gramofonové Závody MM 821 and 822. The recording year is unknown.
} 
The ending of the Festival, and perhaps the most important in Romanian musical history, took place on $22^{\text {nd }}$ September 1958 with Silvestri conducting the première of George Enescu's opera Oedipe. Silvestri's involvement in the performance was complete. Together with the director Jean Rânzescu, he handpicked the baritone David Ohanesian to play the title role. In rehearsal, Silvestri exhibited the same 'exulted thoroughness' that was so characteristic of him, perhaps in part because he was inspired by the never-fading memory of his special relationship with Enescu. However, the authorities wanted some scenes to be cut out since they were considered mystical. Showing probity and professionalism, which was indeed heroic in that particular political context, Silvestri refused point-blank and threatened to step out of the performance. Forced by the danger of a scandal that would resonate abroad, the authorities agreed to have the performance in its original form, but they immediately indexed the recording made at the Opera, cancelled the professional studio recording that was scheduled after the Festival, and strictly forbade any mention of the performance in the Romanian press. Surprisingly, a few days after the première of Oedipe, the magazine Tribuna (The Tribune) in Cluj-Napoca published an extensive review of the performance signed by a certain I. Văleanu. It had probably escaped the censors' vigilance, or perhaps some official had developed a conscience as to the value of the document. In 2018, the composer and professor Cornel Țăranu told me that the critic's name was in fact a pen name - the review was authored by Ilie Balea, a music critic from Cluj who had written extensively in the field in the past decades. The review analysed every musical aspect of the performance. I will quote below Ilie Balea's enthusiastic appreciation:

"Firstly, let me highlight the musical excellence of an ensemble that was instructed with great love for Enescu's oeuvre and with equally great artistic and musical thoroughness. The entire performance is imbued, in an intimate embrace with the score, with Maestro Silvestri's keen, passionate and refined sensibility. The entire performance is constructed in that well-balanced distribution of elements that is characteristic of his symphonic performances. The entire prologue is filled with the poetry of evoking Greece's ancient ceremony: the phrases of the flute, the oboe or the clarinet, with their Auletic resonance, flow with agrestic ease. And an entire ambiance of ancient idyllism takes shape to prepare the contrasting background of the first dramatic cloud that quivers across the final pages of the prologue, preparing to become unleashed in the second act. Under the baton of Constantin Silvestri, this second act becomes a real symphonic treat that is rich in contrasts, with a 
dynamic distribution which climaxes in the dramatic tension of the Sphynx scene and ends forebodingly with the coronation of Oedipus. Constantin Silvestri gives one of the greatest performances of his career. (...) The orchestra of our first opera house achieves remarkable sound, clarity and expressive vibration. Its interventions that are essential in the dramatic development of the tragedy were quite accurate and, under the conductor's unfaltering hand, the orchestra partook actively in the dramatic expression." (Văleanu, 1958, p. 10).

The mention of Oedipe in the press was only possible on one other occasion, in Iași, thanks to the musicologist and professor George Pascu, who had seen the performance. Sadly, the only journal willing to publish it was Flacăra Iașului (The Flame of Iași), which accounts for the limited length of the text. With respect to the conductor, our beloved professor wrote:

"Under the baton of that wonderful creator and deeply sensitive artist, Constantin Silvestri, the Romanian première of the opera Oedipe, dearer to George Enescu than any of his other works, found its fortunate realisation." (Pascu, 1958, p. 2).

The pages of newspapers and magazines from the 1940s and '50s provide a lot of new information about Constantin Silvestri and the Romanian stages of his exceptional, adventurous destiny; it is documentary evidence that patiently awaits to enrich the figure of this remarkable musician.

\section{References}

Bălan, G. (2019). Un meloman insolit se destăinue (II). [The Confessions of an Unconventional Music Lover II], Muzica, 3, 1-27. București: Editura Muzicală.

Bălan, G. (1950). Cu privire la conţinutul socialist în muzică [With regard to the socialist content in music], Contemporanul, September $2 ; 9^{\text {th }}$.

Brucăr, M. (1947). Muzică: Filarmonica - Concert de sonate [Music: The Philharmonic - A Sonata Concert], Contemporanul, April 26th.

Coman, L. (2014). Constantin Silvestri.București: Editura Didactică și Pedagogică, R.A.

Cosma, O. L. (1999). Simfonicele Radiodifuziunii Române [The Symphonic Performances of the SRR Orchestra]. București: Editura Casa Radio.

Deleanu, G. (1948). Stagiunea 1948-1949 [Season 1948-1949]. Contemporanul, 106, October 8th. 
Gheorghiu, V. (1946a) Cronica muzicală. Filarmonica - Orchestra Radio [The Music Review. Philharmonic - Orchestra Radio]. Contemporanul, 6, October 25th, 5.

Gheorghiu, V. (1946b). Jianu la Filarmonică - Radu Aldulescu. [Jianu at the Philhrmonic - Radu Aldulescu]. Contemporanul, 8, November 7th.

Gheorghiu, V. (1946c). Cronică muzicală, [The Music Review]. Contemporanul, 9 , November 15th.

Gheorghiu, V. (1946d). Cronică muzicală [The Music Review]. Contemporanul, 10, November 23th.

Gheorghiu, V. (1946e). Cronica muzicală. Violoniști români - Ed. Lidemberg - C. Silvestri - M. Brediceanu [The Music Review. Romanian Violinists - Ed. Lidemberg C. Silvestri - M. Brediceanu]. Contemporanul, 13, December 12th.

Gritten, J. (1998). A Musician Before His Time. Constantin Silvestri - Conductor, Composer, Pianist. London: Warwick Editions.

Mendelsohn, A. (1948). O nouă orientare în muzică, pe marginea hotărârii C.C. al P.C (b) al Uniunii Sovietice cu privire la creația și critica muzicală [A new orientation in music based on the Directive of the Central Committee of the Communist Party (b) of the Soviet Union]. Contemporanul, March 12th.

Mendelsohn, A. (1951). Raportul la plenara Uniunii Compozitorilor [Report at the Plenary Session of the Composers' Union]. Contemporanul, 260, September 28th.

Pascu, G. (1958). La prima auditie a operei Oedip [At the first audition of Oedipus]. Flacăra Iașului, 3759, September 28th.

Pricope, E. (1975). Constantin Silvestri între străluciri și... cântece de pustiu [Constantin Silvestri between sparkle and ... melancholy songs]. București: Editura Muzicală.

Silvestri, C. (1950). În jurul problemei formei și conținutului în muzică [On the issue of form and content in music]. Flacăra, 30 (134), June 29th.

Vancea, Z., (1950). Pentru o largă dezbatere a problemelor muzicii [For a wide debate of musical issues]. Flacăra, 37, September 17th.

Vasiliu, A. (2018). Primul festival „George Enescu” și opera „Oedip” - istorie umbrită [The first George Enescu Festival and the opera Oedipe - a shadowed history]. Cronica Veche, 9 (92).

Văleanu, I. (1958). Oedip. Tribuna, 39 (86), September 27th, 10.

Vescan, M. (1950). În legătură cu unele confuzii în problema formei naționale și a conținutului socialist în muzică [Concerning some confusions on the issue of the national form and the socialist content in music]. Flacăra, 31(135), August 12th, 4.

Voicu Arnăuțoiu, R. (2013). Constantin Silvestri - biografie necunoscută. [Constantin Silvestri - an unknown biography]. București: Ars Docendi. 
*** Despre dezvoltarea muzicii în R.P.R. Rezoluția Plenarei lărgite a Comitetului Uniunii Compozitorilor din 4-5 februarie. [On the development of music in the People's Republic of Romania. The Resolution of the Larger Plenary Session of the Committee of the Composers' Union on 4th - 5th February], Muzica, 6, 1952, 7-8. 